\title{
Revolutionary Acts: African American Doctoral Students Exercising Racial Agency at a Predominantly White Institution of Higher Education in the United States
}

\author{
Deniece Dortch \\ The George Washington University
}

\begin{abstract}
Because little work exists on the experiences of African-American doctoral students challenging racism in their academic work and academic life, especially at predominantly white institutions $(P W I s)$, this study takes a phenomenological approach to understanding how seven AfricanAmerican cisgender women and men experienced racial agency at one PWI in the Midwest. A phenomenological inductive analysis was used. Findings indicated that racial agency was a necessary coping mechanism to deal with the onslaught of racism they experience. Racial agency is defined as tackling racial issues in public or private discourse and was demonstrated through participant reflections, publishing their scholarship, engaging in social media, and other forms of activism. Racial uplift, campus climate concerns and combating psychological violence were indicated as motivating factors for racial agency, Implications for inclusive practices are discussed.
\end{abstract}

\section{Introduction}

"The students' protest movements [like] Black Lives Matter [and] Young Gifted and Black, have definitely shaped my lens of the academy or shaped how I see the job or work that needs to be done... it does make me think about how I can be more part of the solution in all these movements. From where I am, I may not be able to go to every march and do things like that, [but I can] make sure I'm making people more socially conscious." - Charles

African-American students often are responsible for negotiating race in public and private discourse. This, during an age where facilitated racialized conversations have become an expectation for African-American undergraduate and graduate scholars, and have become commonplace on campus [10], [33]. The expectation that African-American students undertake race-based conversations can be burdensome, tiring, empowering, or invigorating for these students [52], [40], [41], [44]). The ways in which African-American students in higher education address racism traditionally has been through social protest movements [27], [32], [34], [26] and more recently through the use of social media [3], [6], [7], [23]. The primary the focus of racism discourse and action leans toward a broad conversation about higher education in general [7], [30], or specifically targets the experiences undergraduate students [8], [27], [45], [46].

Extant literature addressing African-American doctoral students' experiences with racism, racial trauma, and coping mechanisms for combating the effects of racism is growing, these studies often discuss graduate student experiences in way that marginalize their agency and focus on the campus climate [16], [17], socialization [53], [12], [14], belonging [54] or stress [47], [48]. There has been no significant attention paid to how African-American doctoral students choose to address the racism that they experience at PWIs [52]. Therefore, this research paper centers on how racial agency (an expressed desire to address, pay attention to, handle or feel a responsibility to tackle racialized issues in public or private discourse) [1], [2], [52] is experienced by African-American doctoral candidates at a large PWI in the Midwest United States.

\section{Theoretical Framework}

Using racial microaggressions theory (the everyday subtle and deliberate forms of racism experienced by people of color) as its conceptual lens [41], [44], this empirical research features the narratives of four female African-American and three male African-American doctoral candidates who expressed their desire to respond to racial incidents for the purpose of uplifting the AfricanAmerican community, addressing deficit narratives in the literature, or educating their non-Black peers. These individuals expressed a desire to involve - or send out a call to action to - current and future African-American graduate students to act on racialized injustices as they continued to occur [53].

\section{Racial Microaggressions}

Racial microaggressions are intentional and unintentional verbal and behavioral insults that communicate derogatory and often hostile racialized slights aimed at a person or group through human and environmental encounters [42], [43], [44]. It is the subtle and understated acts of racism that need to be further examined today [41]. Therefore, Sue et al. 
([43]) created a taxonomy to discuss the three forms of microaggressions: (1) microassaults, (2) microinsults, and (3) microinvalidations.

Microassault. A microassault is described as a purposeful interaction meant to attack the intended via discriminatory behavior, name calling, or avoidant behavior. This would include racial epithets, slurs, and anything that would be considered a deliberate and intentional act of racism. Microassaults can be expressed in ways that allow the assailant to remain somewhat anonymous. Examples of this would be to ignore people of color and not serve them in places of business.

Microinsult. Microinsults are much subtler than microassaults. They can be characterized as verbal, nonverbal, or environmental actions that express racial insensitivity or rudeness that can humiliate or degrade a person's racial and ethnic background. Microinsults are demonstrated in the form of snubs and implicit racial bias of which the wrongdoer is not usually aware [42], [43], [44]. Examples that often occur for people of color in higher education include having their professional qualification minimized by being asked if they received their degrees from being in jail, or mistaking graduate of color students for janitorial staff (Montoya, 2014).

Microinvalidation. Microinvalidations are actions that undermine the psychological feelings and experiences of people of color. Examples of microinvalidations of people of color include saying to a person "You speak so well" or "There is no such thing as race" to invalidate the experiences or racial discrimination based on a structured racialized system. Phrases such as this communicate not only a message of tokenism, but also that people of color are unintelligent [42], [43], [44], [20]. Scholars have also discussed multiple examples of subtle forms of racism, discrimination and implicit bias toward people of color in higher education that would also invalidate their experience in the form of racial mocking (eye rolling, sighing, or laughing) on the part of white people when people of color challenge their implicit bias [13], [20], [41], [43], [44]. Sue and company [43] found that the assigning degrees of intelligence based on race and pathologizing communication styles are themes that often persist throughout microaggressions literature.

The subject of microaggressions is important to discuss within the realm of higher education because it provides a lens through which we can understand common and daily assaults on the personhood of people of color while also recognizing the burdensome and tiring toll that being invalidated and discriminated against has on the lives of AfricanAmericans within higher education. Thus, for African-American doctoral students, the significance of racial microaggressions as it relates to their capacity and desire to resist racism at their institutions is important because racial agency could be a coping mechanism used to survive within the academy [53].

\section{Methods}

Data from this project stemmed from a larger critical phenomenological study exploring the racialized experiences of nine African-American doctoral candidates at a PWI. In the larger study, racial agency was identified as a coping mechanism and response to the psychological warfare (that is, the perpetuation of psychological violence, fear, tokenism and isolation) that African-American doctoral students experienced at Anthony Michael University $^{1}$, [52]. This project uses data from seven of the original nine participants. The importance of understanding how African-American doctoral students experience racial agency is useful for understanding how doctoral students navigate the academy. The research question that guided the analysis was: How are African-American doctoral students experiencing racial agency?

\subsection{Participants}

The participants in this study self-identified as African-American. There were four cisgender women and three cisgender men. Assata, Charles, DaShawn, Ivy, Brittany, Robert, Sally were chosen as participants in this project because they had successfully moved through the phases of doctoral study to the point of candidacy, were underrepresented in their respective disciplines, and expressed a commitment and desire to address racial microaggressions and other forms of racial injustice while in school and beyond their academics. They represent the fields of humanities, education, engineering, health sciences, natural sciences, and professional schools.

\subsection{Data Collection}

To understand how African-American doctoral students were experiencing racial agency at predominantly White institution, a purposive sample was used. Purposive samples project "why particular people (or groups) feel particular ways," [29] and convey the process by "which these attitudes are constructed and the role they play in dynamic processes within the organization of the institution" [29]. Nested in the notion of a purposeful sample is an understanding of who an individual is and what

\footnotetext{
${ }^{1}$ Anthony Michael University is a pseudonym being utilized to protect the identity of the institution and the participants of this study.
} 
their position is at the university [53], [29]. Each participant engaged in three 90-minute semistructured interviews over the course of one academic year. The purpose of a three-interview process was to not only search for "the essence of the lived experience," [35] but also to present a holistic view of the participants' subjective experiences by putting their doctoral student experiences in the context of their academic lives beginning from childhood onward. The first interview asked participants to discuss their racialized experiences pre-doctoral study. This current study uses the responses from seven individuals in the study, drawing from the second interview which focused on their day-to-day experiences with race and racism on and off-campus as well as the third interview which focused on how the participants made sense of their everyday racialized experiences [53].

\subsection{Data Analysis}

This research paper used data from a larger study focused on how nine African-American doctoral candidates experienced race at a PWI. The data analysis methods used to carry out this study were in line with phenomenology andvc drew from experts in interpretive qualitative research [35], [49]. The analysis occurred in five stages (see Table 1), [53], [55]. Throughout all stages of the data analysis, there was ongoing interpretation of the research text and the phenomenon of how African-American doctoral students are experiencing racial agency at a PWI. Initially, codes were created by question and I went over each statement line by line. In addition to using emergent codes, I used theoretical codes found in racial agency and microaggressions literature [1]. By constantly cross-checking with the original transcripts, we maintained fidelity to the participants' narratives, grounding interpretations in the data.

Table 1. Stages of Data Analysis Developed for this Research

\begin{tabular}{|l|l|}
\hline Stage 1 & $\begin{array}{l}\text { Organizing the dataset into texts } \\
\text { - Itrative reading of texts } \\
\text { - Preliminary interpretation of texts to facilitate coding }\end{array}$ \\
\hline Stage 2 & $\begin{array}{l}\text { Identifying (participant) constructs } \\
\text { - Coding of data using NVivo software }\end{array}$ \\
\hline Stage 3 & $\begin{array}{l}\text { Identifying (researcher) constructs } \\
\text { - Grouping constructs into sub-themes }\end{array}$ \\
\hline Stage 4 & $\begin{array}{l}\text { Synthesis and theme development } \\
\text { - Grouping sub-themes into overarching themes } \\
\text { Further elaboration of themes }\end{array}$ \\
\hline Stage 5 & $\begin{array}{l}\text { Illumination and illustration of phenomena } \\
\text { - Linking the literature to the themes identified above } \\
\text { Reconstructing interpretations into stories }\end{array}$ \\
\hline & (Adapted from [55]) \\
\hline
\end{tabular}

\subsection{Positionality}

I am an African-American woman educational research social scientist who has attended predominantly white institutions for much of my academic upbringing. I have tackled racism in the form of local, regional and national presentations, social media, most recently in publications. Throughout my intellectual pursuits, I have noticed that African-American students choose to resist racism in a multitude of ways and believe that utilizing various approaches to addressing racism can ultimately improve the university environment for the African-American students attending PWIs. I find that African-American doctoral students and their experiences with racial agency, including understanding their motivations to address racism in both in public discourse and in private discourse are important to research because there are few AfricanAmerican doctoral students who successfully move through the academic pipeline. I wish to provide current and future students with examples of how they may use their voices, their writing, and their research to challenge the individual and structural racial injustices that they may be experiencing on their campuses. I believe that there is power in exercising agency, and this power can be used toward making the university campus climate a more welcoming place for African-American and Black students to thrive if we as academicians, practitioners, and policymakers create environments in which they can do so.

\subsection{Trustworthiness}

To ensure trustworthiness and accurate representation of participant' stories, I engaged in member checks. Member checks are essential to elevating a study's credibility [19], [24], [36]. As elaborated by Shenton [36], "checks relating to the accuracy of the data may take place 'on the spot' in the course, and at the end of the data collection dialogues" (p. 68). In each subsequent interview, the author asked the participants to clarify the interpretations about the previous conversation and checked in with them about questions that she had about the last conversation. The author also agreed to share findings with them after the study for their reactions.

\section{Findings}

Racial agency can be highly influenced by the greater campus climate and institutional culture, but it can also be impacted by the individual experiences or interactions. Again, racial agency is an expressed a desire to address, pay attention to, handle or feel a responsibility to tackle racialized issues in public and private discourse [1], [2], [52]. The findings presented here are the experiences of agency that Charles, DaShawn, Sally, Assata, Robert, Ivy, and Brittany encountered during their years as doctoral candidates at the predominantly White institution that they attended. Findings have been categorized by motivations for racial agency, racial agency in 
public discourse and racial agency in private discourse.

\subsection{Motivations for Racial Agency}

Participants DaShawn, Charles, and Robert expressed their motivations to combat racial microaggressions by indicating their desire to confront racial issues directly, which stemmed from a sense of obligation to make the campus environment a little less hostile for them and for others. Robert is an example of someone who is motivated by a desire to give back to his community: "Honestly, looking at my own 'success' ... for me it doesn't really mean much unless I'm able to help someone else get into a position that they want to be." Here we see that Robert is motivated by racial uplift. Below are examples from DaShawn and Charles.

DaShawn describes feeling a responsibility to create classroom environments for students that is less racially hostile.

I've had such an issue with the way professors are like creating spaces or conditions which can be violent or traumatic for students. I feel like I have some responsibility, right, to be in that space and create that counterculture to counter that space so that I am not sitting here thinking, "Oh! Well, you're just a casualty of having a system that sucks." -DaShawn

"I definitely feel a responsibility to make sure that folks don't leave class thinking negatively about Black folks, particularly if that's the only conversation that's being had about Black folks, or folks of color."

-DaShawn

Charles describes below that his motivation stems from recent protest movements toward racial equity freedom and justice. He goes on to express that as a Black student he feels a sense of obligation to pay attention to what is happening around him and to tackle racial injustices that are happening.

Well, [clears throat] the students' protest movements or Black Lives Matter like Young Gifted and Black, all those things have definitely shaped my lens of the academy or shaped how I see the job or work that needs to be done... being part of the academy how - what work needs to be done, umm, they definitely take a CPU [Central Processing Unit also known as "head space"] space though "cause these are things that, you know, maybe white students or white faculty are not concerned about. They can kind of look at this protest and these movements and say "oh, wow that's great. They should, you know, they should have, equal rights or like freedom of speech" and then they just kind of ignore it, whereas a Black student you can't ignore these movements that are kind of the hurt and the anguish it's getting expressed, you have to - you have to address it, yeah, at least me personally I think like I had to address it, I have to talk about it, I have to process it. 'It's gonna take up CPU hours. You had to kind of address it [head] on, I mean it doesn't necessarily shape my research which is kind of very narrowly focused and very technical, but it does make me think about how I can be more part of the solution in all these movements from where I am. I may not be able to go to every march and do things like that, but what can I do to address some of the concerns that are being raised by, you know, these movements and it just make sure I'm making people more socially conscious and things like that, so it definitely takes a CPU hours of the day, but I think it's something that's important, it's something I can't just disengage from and be a student. I'm a Black student so this is a part of the burden, so to speak. -Charles

As is evidenced through these quotes, these participants are motivated to address racial issues for various reasons. Some of the motivations are due to helping current and future students engage in an environment in which is less racially hostile. Other reasons stem from being in an environment in which protest movements are occurring throughout the country. Lastly, these findings describe that their motivations for tackling racial issues stem from feeling a sense of obligation to uplift their communities.

\subsection{Racial Agency in Public Discourse}

The African-American students in this study were often tasked with the responsibility of negotiating race in public discourse. Participants Assata and Sally expressed a desire to address deficit narratives that have been expressed in the literature by using their own research as a tool. Below are a few examples of the ways they envision their work fitting into a broader narrative:

I think what it means to be on this campus, it means to take full [Pause] to be fully engaged ...so that I can present quality research on communities that are normally exploited in other people's research. ... I think the bottom line of what I'm trying to say is for me to be here means that I take full advantage of everything they offer that I can take back to a community of other black folks and a community of scholars...to explore marginalized folks in literature, marginalized black women, marginalized black mothers and to represent them in a way that does not focus on pathologizing them, but to represent them as whole people, to bring their voices to the literature versus to impose a dominant perspective on them. -Assata 
I really try to use race and theories that involve race, power, privilege, identity and to try to move the conversations towards how do we fix [structural barriers]. And what does this look like practically speaking? What programs do we need to develop? What's working, what's not working? Why is it not working? As a way to contribute to the literature. -Sally

As doctoral students, both Assata and Sally have chosen to use their research as way to express their racial agency in public spaces. Evidenced in the quotes above, they are choosing a solutions-based approach to either represent Black people in a more positive way. They are also addressing systemic and structural barriers by considering how to address social injustices outside of theoretical space into practical ones.

\subsection{Racial Agency in Private Discourse}

Participants are often tasked with the responsibility of addressing racial microaggressions and other racial injustices in private. The ways that they often address these issues are in one-on-one conversations with peers and others. In this section, social media was used as a tool to inform participants of racism that was occurring throughout the country and it was used to inform others of ways to address their involvement with structural and systemic oppression. Below, participants Ivy and Brittany describe feeling an expectation of spearheading or tackling race-based conversations which frequently produced complex emotions.

Ivy describes an instance when she was online using Facebook and spent her entire day reading research papers and comments about Black people in the United States dying at the hands of police brutality. She then conversed privately with family and friends and questioned whether White students shared the responsibility of addressing racism in the same ways that she did.

So, aside from the fact that, you know, innocent Black people are dying because the black body is seen as threatening, it causes[me] to be like a conscious Black student. And by that, I mean someone who like cares about these issues. To be a grad student during these times, it's like you wake up, you go on Facebook, and that's the first thing that you see. So you go on and you read this research paper, and you read [comments] and then you read [a different perspective] about it then you go and you talk to your friends about what is happening. And then it's just like, you spent your entire day just doing that. I'm like, do White grad students do that? Probably not. So the white students don't have to take time away from their studies to, like, have these conversations [about racism], and to, like, talk to their friends [and others] about, like, the things that have happened. As Black grad students...we [must] have these conversations.

Brittany describes a time in which she felt responsible for teaching her White peers about privilege, power and difference as one of the few African-American women in the sciences that her peers may encounter. In the example, she describes inviting her peer who is also her co-worker to an event focused on White privilege.

For some of these people I know for a fact that I'm the first Black person they've ever interacted with in this close of proximity...Part of me is going out of my way to teach a couple of my classmates...Most of the time it involves me taking an extra step out of my day to be like, 'Hold on. Let me teach my white male lab mate about his privilege.' And so that means, like seeing events on Facebook that I normally wouldn't go to and inviting my friends to it because they would benefit from it and indirectly, I would benefit from having to educate them. [For example] one of the offices on campus hosted 'Unpacking your White Privilege' workshop and I invited my labmate up who is working through the early stages of understanding his privilege which translates to white guilt. Then [he] wanted to debrief after [the workshop] with me because I'm [his] only Black friend.

As illustrated by both Ivy and Brittany, exercising racial agency in private can be as laborious as tackling racial issues in public. In private, whether it be the mental and emotional energy spent on Facebook making comments, reading research papers from a variety of perspectives, or conversing with friends, family and colleagues about the racial privilege, participants maintain that they felt a sense of obligation to engage.

The African-American students in this study were often engaged in racial discussions both in public and in private. Facilitating racialized conversations in public and in private were not only an expectation for the participants, but were regarded as commonplace. Participants described feeling an expectation of spearheading or tackling race-based conversations because they were one of few Black people in their programs, because they wanted to change deeply held negative beliefs about AfricanAmericans and because the wanted to make the environment a more inviting and less racially hostile for themselves and future students. The AfricanAmericans in this study variously described their experiences as burdensome, and tiring but consistently described wanting to change their present circumstances. Assata, Brittney, Charles, DaShawn, Ivy, Robert, and Sally expressed their desire to respond to racial incidents which are happening to them or around them for uplifting the Black community or to address deficit narratives that have been expressed in the literature. 


\section{Discussion}

Participants in the study demonstrated the ways in which they understood how they were being perceived by other students, faculty and colleagues and that knowing often fueled their racial agency. The findings indicated that the participants desired to confront racial issues because of a sense of obligation to make the campus environment less hostile for them and others. Their engagement with racism also came from a need to move marginalized voices and experiences to the center of public discourse and add to larger conversations about equity, inclusion, and freedom.

Racial microaggressions often permeate a doctoral student's sense of belonging, their socialization into the academy, their self-efficacy and their sense of racial agency. Daily manifestations of racism and racial discrimination influence the way that they experience others by inciting mistrust, fueling a loss of self-confidence, increasing anger and indignation, and increasing stress and other psychological issues [53], [52], [40], [48]. The findings provided at least one example of this in each case. DaShawn did not want students to be subjected to a "violent system that sucks." Ivy expressed contempt at the thought that her White peers did not have to spend all day discussing "Black people dying." Brittany lamented over the extra work it took to invite her White lab mate to a workshop that she would not normally attend so that he could learn about his White privilege. Students are burdened, tired and exhausted with these responsibilities. These feelings of exhaustion are described by scholars as racial battle fatigue [11], [40], [39], a phenomenon that takes into consideration the psychological (disappointment, resentment, surprise), physiological (i.e. insomnia, headache), and behavioral (social withdrawal, self-doubt) responses to battling microaggressions [11], [40], [39], [41]. Predominantly white institutions are ripe for producing racial battle fatigue resulting from experiencing and addressing racial microaggressions [39].

While the presence of racial battle fatigue is not a new critique, what makes this study unique is twofold: (1) that participants in the study recognize that individual actors are participating in a system that is could be described as inherently racist and psychologically violent and, therefore, the same faculty members, peers and other "agents of change" that may share diversity agendas and social justice values are operating in a system that is still oppressive and they themselves may in turn be oppressing the individuals they are charged with supporting; and (2) linking of participants' understanding of the cultural politics that exist in connection with their motivations to engage informs their racial agency. How and what constitutes difference among their various racialized experiences, the seriousness and importance it is given in representation, and the way in which premiering racialized issues that shape the doctoral experience now in academia acknowledges some interruption from the previous forms of analysis [50]. Frankly, the new cultural politics of racial difference consists of innovative responses to the detailed circumstances of our present moment-especially those of marginalized actors who shirk negative selfrepresentations [25], [48], [52].

In this new culture, racial agency is at the forefront, which demands that predominantly White institutions be less psychologically violent, and racially hostile [5], [52], [22]. It embraces the distinct expressions of doctoral students who attempt to empower and enable social action and, if possible, "to enlist collective action for the expansion of freedom, democracy and individuality" ([50] p.129). This strategy, however, places African-American doctoral students in a double-bind while connecting their academic, social, emotional, and psychological undertakings to the fundamental, structural overhaul of these institutions [50].

Without social or political pressure from both inside and outside academia, transformation or reformation becomes a challenge and disruption is improbable [52], [15], [22], [50]. Thus, racial agency was a necessary tool for the African-American doctoral students in the study. Further, the motivations to be agents of change within the academy for the participants is a permanent antecedent condition, which means it triggers African-American doctoral students to develop racial agency and other tools for survival within the academy.

\section{Conclusion}

This study explored how seven AfricanAmerican doctoral candidates experienced racial agency as a strategy to combat the racism and racialized microaggressions at one PWI in the Midwest United States. This inquiry supports the extant literature describing coping mechanisms that African-American use (participant reflection, addressing racialized issues, using their research) in response to oppression within doctoral programs [10], [17], [16], [14], [18], [25], [31], [48]. These survival strategies exhibited by racial agency was used for coping with onslaught oppression, as accented by my participants.

These accounts help us to understand how those affected by racism make sense of the world around them. Specifically, the literature highlights how individuals perceive racism as unjust and how individuals can use their knowledge and skills to deal with racism and oppression [16], [46], [37]. AfricanAmerican doctoral students may utilize racial agency 
in response to the symptoms racism and racialized microaggressions, which vary depending on context.

\section{Implications}

This study names racial agency as a phenomenon that is experienced by African-American doctoral students. The conditions and environments within which many African-American doctoral students currently participate can be psychologically violent, racially hostile, and unwelcoming. The implications for this study are both individual and structural. However, I hope that the findings and suggestions I offer from the study can tackle how AfricanAmerican doctoral students are demonstrating racial agency. While this study focuses on the experiences of seven doctoral candidates, it is not meant to be generalizable, but the lessons learned here can be transferrable to other students of color who may be experiencing racial agency at predominantly white institutions. Moreover, the implications outlined for practice can help institutions in disrupting the usual cycles of perceived and experienced psychological violence by taking actions that emotionally, physically, and financially support the persistence and success of African-American doctoral students.

African-American doctoral students experiencing racial agency provides us with an understanding of how racism and racial microaggressions are addressed by graduate students, which can provide administrators and faculty with additional insights on how they can create socially just and culturally inclusive campus environments whereby underrepresented students have the support to academically thrive. Current administrators and policymakers who serve as institutional actors could make paradigmatic changes to create inclusive policies and practices to interrupt systems of violence. These shifts could include institutions moving away from incremental progress (that is, focusing on meeting diversity quotas as counting toward equity; [4], and move toward complete equity-minded cultural shifts that include equityminded transformations (meaning, deepening commitments to equity through inquiry and practitioner knowledge; justice as fairness - equal distribution of resources among equals and providing greater distribution to racially marginalized students; enacting justice as care - freedom from oppression [9]. It is important that predominantly white institutions engage in the practice of transparency and they begin to engage in institutionalized racial agency - acknowledging our history and legacy of slavery and racial oppression, sharing a responsibility to tackle racialized inequity, transforming institutional processes, which perpetuate racialized microaggressions, hostility, and violence.

\section{References}

[1] K. L. Bentley-Edwards, "Hope, agency, or disconnect: Scale construction for measures of Black racial cohesion and dissonance". Journal of Black Psychology, 42.1, 2016 73-99.

[2] K. L., Bentley-Edwards, \& C. Chapman-Hilliard, "Doing race in different places: Black racial cohesion on Black and White college campuses," Journal of Diversity in Higher Education, 8.1, 43, 2015.

[3] A. Brock, "From the blackhand side: Twitter as a cultural conversation," Journal of Broadcasting \& ElectronicMedia, 56, 2012,529-549. doi:10.1080/0883815 1.2012.732147

[4] J. S. Brooks, (Ed.). "Confronting racism in higher education: problems and possibilities for fighting ignorance, bigotry and isolation," IAP, 2013.

[5] R. Clark, N. B. Anderson, V. A. Clark, and D. R. Williams, "Racism as a stressor for African-Americans," American Psychologist, 54.1, 1999, 805-816.

[6] T. Correa \& S. H. Jeong, "Race and online content creation: Why minorities are actively participating in the Web," Information, Communication \& Society, 14, 2011, 638-659. doi:10.1080/1369118x.2010.514355

[7] C. H., Davis III, R. Deil-Amen, C. Rios-Aguilar, \& M. S. González Canché, "Social media, education, and community colleges: A research synthesis and implications for the of two-year institutions," Community College Journal of Research and Practice, 39.5, 2015, 409-422.

[8] M. Davis, Y. Dias-Bowie, K. Greenberg, G. Klukken, H. R. Pollio, S. P. Thomas, \& C. L. Thompson, "A fly in the buttermilk: descriptions of university life by successful black undergraduate students at a predominately white southeastern university," The Journal of Higher Education, 75.4, 2004, 420-445.

[9] A. C. Dowd, \& E. M. Bensimon, "Engaging the" race Question": Accountability and Equity in US Higher Education,' Teachers College Press, 2015.

[10] E. Ellis, "The impact of race and gender on graduate school socialization, satisfaction with doctoral study and commitment to degree completion," Western Journal of Black Studies, 25.1, 2001, 30-45.

[11] K. J. Fasching-Varner, K. Albert, R. Mitchell, \& C. Allen, "Racial battle fatigue in higher education: Exposing the myth of post-racial America," Rowman \& Littlefield, 2015.

[12] P. Felder, "On doctoral student development: Exploring faculty mentoring in the shaping of AfricanAmerican doctoral student success," The Qualitative Report, 15.3, 2010, 455-474.

[13] J. Franklin, "Racial Microaggressions, Racial Battle Fatigue, and Racism-Related Stress in Higher 
Education," Journal of Student Affairs at New York University, 12, 2016, 44.

[14] S. K., Gardner, \& K. A. Holly, "Those invisible barriers are real": The progression of first-generation students through doctoral education,' Equity \& Excellence in Education, 44.1, 2011, 77-92.

[15] M. Gasman, C. Gerstl-Pepin, S. AndersonThompkins, "Negotiating power, developing trust: Transgressing race and status in the academy," Teachers College Record, 106.4, 2004, 689-715.

[16] G. Gay, "Navigating marginality en route to the professoriate: graduate students of color learning and living in academia," International Journal of Qualitative Studies in Education. 17.2, 2007, 265-288

[17] R. E. Gildersleeve, N. N. Croom, \& P. L. Vasquez, “"Am I going crazy?!" A critical race analysis of doctoral education,' Equity and Excellence in Education, 44.1, 2011, 93-114.

[18] K. Griffin, "Striving for success. A qualitative exploration of competing theories of high achieving black college students' academic motivation", Journal of College Student Development, 47.4, 2006, 384-400.

[19] E.G. Guba, "Criteria for assessing the trustworthiness of naturalistic inquiries," Educational Communication and Technology Journal, 29.2, 1981, 75-91.

[20] S. R Harper, "Race without racism: How higher education researchers minimize racist institutional norms," The Review of Higher Education, 36.1, 2012, 929.

[21] N. P. Kafle, "Hermeneutic phenomenological research method simplified" Bodhi: An Interdisciplinary Journal, 5.1, 2013, 181-200.

[22] S. E. King, \& J. R Chepyator-Thomson. "Factors affecting the enrollment and persistence of AfricanAmerican doctoral students", Physical Educator, 53,1996, $70-180$

[23] R. J. Lee-Won, T. N. White, \& B. Potocki, "The Black catalyst to tweet: the role of discrimination experience, group identification, and racial agency in Black Americans' instrumental use of Twitter," Information, Communication \& Society, 2017, 119.

[24] Y.S. Lincoln "Emerging criteria for quality in qualitative and interpretive research," Qualitative Inquiry, $1.3,1995,275-289$.

[25] D. Mellor, "Responses to racism: A taxonomy of coping styles used by aboriginal Australians," American Journal of Orthopsychiatry, 74.1, 2004, 56-71.

[26] D. L. Morgan \& C. H. Davis III, Student activism, politics, and campus climate in higher education. Routledge, 2019
[27] A. Morris, "Black southern student sit-in movement: An analysis of internal organization," American Sociological Review, 1981, 744-767.

[28] C. Moustakas, Phenomenological research methods, Sage, 1994

[29] T. Palys, Purposive sampling. In L. M. Given (Ed.). The Sage encyclopedia of qualitative research methods, 2 , Sage, Thousand Oaks, CA, 2008, 697-698.

[30] L. Parker, D. Deyhle, \& S. Villenas, Race Is... Race Isn't: Critical Race Theory and Qualitative Studies in Education. Perseus Books Group, Boulder, CO, 1999

[31] S. M. Patterson-Stephens \& L. M. Vital, "Black doctoral women: Exploring barriers and facilitators of success in graduate education," Academic Perspectives in Higher Education, 3.1, 2017, 5 .

[32] R. A. Rhoads, Freedom's web: Student activism in an age of cultural diversity. Johns Hopkins University Press, Baltimore, Maryland, 1998

[33] S. J. Robinson, "Spoke tokenism: Black women talking back about graduate school experiences," Race Ethnicity and Education, 16.2, 2013, 155-181.

[34] I. Jo Rogers, "The Black campus movement: Black students and the racial reconstitution of higher education 1965-1972," Springer, 2012

[35] I. Seidman, "Interviewing as qualitative research: A guide for researchers in education and the social sciences. New York: Teachers College Press, 1998

[36] A. K. Shenton, "Strategies for ensuring trustworthiness in qualitative research projects. Education for information, 22.2, 2004 63-75.

[37] K. Shorter-Gooden, "Multiple resistance strategies: How African-American women cope with racism and sexism," Journal of Black Psychology, 30.3, 2004, 406425 .

[38] A. Smith, "African-Americans and technology use: A demographic portrait. Pew Research Center, 2014 http://www.pewinternet.org/files/2017/05/African-Ameri cans-and-Technology-Use.pdf

[39] W. A. Smith, M. Hung, \& J. D. Franklin, "Racial battle fatigue and the miseducation of Black men: Racial microaggressions, societal problems, and environmental stress," The Journal of Negro Education, 2011, 63-82.

[40] W. Smith, W. Allen, \& L. Danley, "Assume the position ... you fit the description': Psychosocial experiences and racial battle fatigue among AfricanAmerican male college students,"American Behavioral Scientist. 51, 2007, 551-578.

[41] D. Solorzano, M. Ceja, \& T. Yosso, "Critical race theory, racial microaggressions, and campus racial climate: The experiences of African-American college students," Journal of Negro Education, 2000, 60-73. 
[42] D. W. Sue, "Microaggressions in everyday life: Race, gender, and sexual orientation," John Wiley \& Sons, 2010.

[43] D. W. Sue, K. L. Nadal, C. M. Capodilupo, A. I. Lin, G. C. Torino, \& D. P. Rivera, "Racial microaggressions against Black Americans: Implications for counseling," Journal of Counseling and Development: JCD, 86.3, 2008, 330-338.

[44] D. W. Sue, C. M. Capodilupo, \& A. Holder, "Racial microaggressions in the life experience of Black Americans," Professional Psychology: Research and Practice, 39.3, 2008, 329.

[45] B. D. Tatum, "Why are all the black kids sitting in the cafeteria: And other conversations about race," Basic Books, 1997

[46] B. Tatum, "Talking about race, learning about racism: The application of racial identity development theory in the classroom," Harvard Educational Review, 62.1, 1992, $1-25$.

[47] K. A. Truong, "Racism and racial trauma in doctoral study: How students of color experience and negotiate the political complexities of racist encounters," 2010.

[48] K., Truong, \& S. Museus, "Responding to racism and racial trauma in doctoral study: An inventory for coping and mediating relationships," Harvard Educational Review, 82.2, 2012, 226-254.

[49] M. van Manen, "From meaning to method," Qualitative health research, 7.3, 1997, 345-369.

[50] C. West, The cornel west reader. Basic Books, 1999.

[51] M. Wilcke, "Hermeneutic phenomenology as a research method in social work," Currents New Scholarships in Human Services. University of Calgary Press. 2002, Retrieved 12/10/14, http://www.ucalgary.ca/ currents/files/currents/v1n1_wilcke.pdf

[52] D. Dortch, Interrupting the usual: African-American doctoral students experiencing race at a predominantly White institution. The University of Wisconsin-Madison, 2016.

[53] Dortch, Deniece. "The strength from within: A phenomenological study examining the academic selfefficacy of African American women in doctoral studies." The Journal of Negro Education 85.3, 2016, 350364.

[54] D. Dortch, and C. Patel, "Black undergraduate women and their sense of belonging in STEM at predominantly White institutions." NASPA Journal About Women in Higher Education 10.2, 2017, 202-215.

[55] Ajjawi, R., \& Higgs, J. (2007). Using Hermeneutic Phenomenology to Investigate How Experienced Practitioners Lear $\mathrm{n}$ to Communicate Clinical Reasoning. The Qualitative Report, 12(4), 612-638. Retrieved from https://nsuworks.nova.edu/tqr/vol12/iss4/6 